in it, rather than destroying it entirely, as too often was the endeavour of earlier generations. It has been noted recently that a feeling of disillusion and pessimism is appearing among Africans; but $\mathrm{Mr}$. Smith looks to win the co-operation of the African in his own development, and in this connexion regards hopefully the interest he is beginning to take in the systematic study of his culture and institutions.

\section{Training for Management}

DURING recent years, considerable interest has developed in the possibilities of specialised training for business management. Such training, it is recognised, is not a substitute for experience but a supplement, or rather a preparatory basis, which provides a broader foundation on which experience can build. The applications of science to industry, intensified world competition, the increasing complexity of industrial organisation and other factors have combined to make the task of successful management far more complicated and difficult than it was in the past. To provide for the systematic training of men for responsible posts in business, a Department of Business Administration was established at the London School of Economics in 1930 through the joint efforts of leading business firms and the authorities of the School. Selected students are given fulltime training in the broad principles of business administration, and throughout the course efforts are made to keep the teaching in close touch with reality through discussions opened by business men and by visits to factories, shops and offices. Special attention is paid to marketing, retail management and sales management, and instruction in these subjects is based on fresh investigations into current practice. The recently issued prospectus of the Department for the coming session shows that during the past three years nearly fifty students have passed through it, most of them university graduates. Last summer, the Department began an experiment in training which was designed to be of practical help in bridging the gap between university study and entry into business. Under this scheme, which is being extended during the coming session, a number of firms offer appointments to university graduates of high standing who are selected by them and approved by the Department on condition that they attend the specialised business course during the academic year from October until June.

A management course for industry and commerce, which covers departmental functions, methods, problems, underlying sciences and managerial mental activity is being given by Mr. W. R. Dunlop, 57 Gordon Square, London, W.C.1. Mr. Dunlop offers a complete outline of knowledge relevant to the management and direction of an organisation departmentally and as a whole. There is also a personal side devoted to individual diffioulties and requirements. The course is useful, not only to those who manage or who expect to, but also to professional and technical experts from the point of view of co-operative efficiency, and has been taken, either orally or by correspondence, by experienced account- ants, managers, industrial chemists and engineers in some of the largest industrial concerns. Critically selected references for reading are included. The course, which is personal and private, has its advisory professional practitioners from whom expert information and advice can be obtained when required, thereby combining the chief advantage of institutional instruction with private tuition.

\section{Medieval Spices}

Commentrng on a suggestion in a recent review of a leochbook in NATURE $(134,270$, Aug. 25, 1934) that certain spices "must have been hard to come by in fifteenth century England", Mr. G. M. Meyer, of 38 Manor Park Gardens, Edgware, points out that ginger and pepper must have been usual articles of commerce in the years $1300-1$, and presumably in later years, since they were then the subject of specified King's dues and of authorised brokerage charges at the port of Sandwich. The mere fact that a commodity is imported into a country does not necessarily imply that it is not difficult to obtain, at any rate by those not blessed with wealth and influence. The interesting historical account of pepper given by Fluckiger and Hanbury ("Pharmacographia"; London, Macmillan and Co., 1879) shows that it was only after the Portuguese, incited in part thereto by the high price of pepper, had discovered a sea-passage to India in 1498, that the cost of this condiment began to fall, and the following quotations from these authors seem to indicate that pepper was usually too uncertain in supply and too expensive to be regularly obtainable, except by the wealthy. "The price of pepper during the middle ages was always exorbitantly high, for the rulers of Egypt extorted a large revenue from all those who were engaged in the trade in it and other spices. The general prevalence during the middle ages of pepperrents, which consisted in an obligation imposed upon a tenant to supply his lord with a certain quantity of pepper, generally a pound, at stated times, shows how acceptable was this favourite condiment and how great the desire of the wealthier classes to secure a supply of it when the market was not always certain." Ginger was apparently not so commonly a subject of comment and controversy in medieval times as pepper, but it is on record that during the thirteenth and fourteenth centuries a pound of ginger cost about the price of a sheep.

\section{British Association Mathematical Tables}

The issue of Nature of March 17 gave a historieal account of the British Association's work since 1888 in the calculation of Bessel functions and of the financial difficulties which have impeded publication. It was pointed out that unless funds were provided, there was a danger that all this labour would result merely in a manuscript locked up in a fireproof safe. We are glad to hear that the appeal for funds has been successful; the British Association has contributed $£ 100$ and the Royal Society $£ 50$, and the publication of the tables is now assured. They will form vols. 6 and 7 of the Association's collection. The first three volumes have already been noticed 
in this journal. Vol. 4, "Cycles of Reduced Ideals in Quadratic Fields", prepared by Dr. E. L. Ince, was published in August, and vol. 5, containing the prime factors of all numbers from 1 to 100,000 , is now in the press, and it should be available before the end of the year. This valuable set of tables is not as well known as it should be, possibly because it has not been handled by a publishing firm. New arrangements have now been made, and in future the tables will be sold by the Cambridge University Press.

\section{Seismological Committee of the British Association}

THE thirty-ninth report of this Committee is chiefly concerned with the maintenance of the International Seismological Summary. The University of Oxford has agreed to provide room and part of the working expenses until the time comes when these can be met entirely from sources outside the University, such as the International Union for Geodesy and Geophysies, the Crombie and Gray-Milne funds, and the British Association grants. The summary for the third quarter of 1930 is now in course of preparation, and in this the Committee is able to avail itself of the new Jeffreys-Bullen tables, the accuracy of which will greatly help in the determination of epicentres. The precision of the work now being carried on is evident from the suggestion that the time is approaching when the spheroidal form of the earth will have to be taken into account in the estimation of distances.

\section{International Physiological Congress}

THE Fifteenth International Physiological Congress will be held in Leningrad and Moscow on August 9-17, 1935, under the presidency of Prof. I. P. Pavlov. Arrangements will be made for visits, after the Congress, to various parts of Russia. The International Committee consists of Profs. Bottazzi, Frank, A. V. Hill, Howell, Johansson, Lapicque, Pavlov and the Congress Committee of Profs. Pavlov (president), Orbeli, Palladin, Beritoff (vicepresidents), Fedorov (general secretary), Volborth, Koshtojanz (secretaries). It will greatly assist the work of the Committee if physiologists intending to be present enrol as early as possible. Correspondence concerning the Congress should be addressed to Leningrad, Main P.O., Box 13.

\section{Iron and Steel Institute}

AT the general meeting of the Iron and Steel Institute in Brussels which opened on September 10, it was announced that H.M. the King of the Belgians, Leopold III, has honoured the Institute by accepting nomination as honorary member. This continues the tradition by which H.M. King Leopold II (1874-1909) and H.M. King Albert I (1913-1934) had been honorary members of the Institute. The Council is proposing Sir Harold Carpenter for election as president at the annual meeting of the Institute in May 1935, and Mr. James Henderson, deputy chairman and general manager of the Appleby Iron Company, Ltd., and of the Frodingham Iron and Steel Company, Ltd., and president of the British Iron and Steel Federation, has been elected honorary treasurer in succession to Sir Harold Carpenter, who is resigning at the end of September. The date of the annual meeting for 1935 will be May 1-3.

\section{Announcements}

THE following gold medals of the North East Coast Institution of Engineers and Shipbuilders have recently been awarded: Engineering Gold Medal to W. T. Bottomley, E. W. Corlett and Frank Piercy for their paper entitled "The Possibilities of Applying Improve. ments Effected in Modern Land Power Plant to Ship Propelling Machinery"; Shipbuilding Gold Medal to N. M. Hunter for his paper entitled "The ElectricWelded Ship Peter G. Campbell".

THE second meeting of the Microchemical Club will be held at Reading on September 29. At 11 p.m. the Club will meet at the University for the discussion of papers, and after luncheon a visit will be paid to the National Institute for Research in Dairying, Shinfield, where demonstrations will be given.

DURING the forthcoming winter it will be passible for Mr. H. V. Garner, the guide demonstrator of the Rothamsted Experimental Station, Harpenden, and other members of the staff, to give lectures to chambers of agriculture and horticulture, farmers' clubs, farm workers' associations, agricultural societies, etc., on the Rothamsted experiments. All communications regarding lectures should be addressed to the Secretary, Rothamsted Experimental Station, Harpenden, Herts.

A CONFERENCE of malting barley growers and malting barley buyers and maltsters will be held at the Rothamsted Experimental Station on October 10, at 11.30 a.m., when the chair will be taken by Mr. Stanley O. Ratcliff, president of the National Farmers' Union. The purpose of the conference is to enable buyers and maltsters to meet growers and discuss with them the grading of samples. Further information can be obtained from the Secretary, Rothamsted Experimental Station, Harpenden.

ApPLications are invited for the following appointments, on or before the dates mentioned :-A demonstrator in applied mechanies at the Royal Naval College, Greenwich-The Adviser on Education, Admiralty, Whitehall, S.W.1 (Sept. 17). Veterinary officers for the Administrative Counties of East and West Suffolk-The Clerk of the Local Authority, County Hall, Ipswich (Sept. 20). Civilian garrison engineers for the Establishment for Engineer Services at Army stations in Great Britain and Northern Ireland-The Under-Secretary of State (C. 5), The War Office, London, S.W.1 (Sept. 22). A lecturer in power plant at the Polytechnic, Regent Street, London, W.1-The Director of Education (Sept. 24). A botanical specialist and an animal breeding specialist in the Fouad I Agricultural Museum, Egypt-The Under Secretary of State, Ministry of Agriculture, Cairo (Sept. 30). A lecturer in physiology at the University of Cape Town-The Secretary, Office of the High Commissioner for the Union of South Africa, Trafalgar Square, London (Oct. 17). 